\title{
Chemical Interactions between Fibrosarcoma Cancer Cells and Sensory Neurons Contribute to Cancer Pain
}

\author{
Iryna A. Khasabova, ${ }^{1}$ Cheryl L. Stucky, ${ }^{6}$ Catherine Harding-Rose, ${ }^{1}$ Laura Eikmeier, ${ }^{4}$ Alvin J. Beitz, ${ }^{5}$ Lia G. Coicou, ${ }^{2}$ \\ Amy E. Hanson, ${ }^{3}$ Donald A. Simone, ${ }^{1}$ and Virginia S. Seybold ${ }^{2}$ \\ Departments of ${ }^{1}$ Diagnostic and Biological Sciences and ${ }^{2}$ Neuroscience and ${ }^{3}$ Pharmacology Graduate Program, University of Minnesota, Minneapolis, \\ Minnesota 55455, ${ }^{4}$ Comparative and Molecular Biosciences Graduate Program and ${ }^{5}$ Department of Veterinary and Biomedical Sciences, University of \\ Minnesota, St. Paul, Minnesota 55108, and ${ }^{6}$ Department of Cell Biology, Neurobiology, and Anatomy, Medical College of Wisconsin, Milwaukee, Wisconsin \\ 53226
}

In an experimental model of cancer pain, the hyperalgesia that occurs with osteolytic tumor growth is associated with the sensitization of nociceptors. We examined functional and molecular changes in small-diameter dorsal root ganglion (DRG) neurons to determine cellular mechanisms underlying this sensitization. The occurrence of a $\mathrm{Ca}^{2+}$ transient in response to either $\mathrm{KCl}(25 \mathrm{~mm})$ or capsaicin ( $\left.500 \mathrm{~nm}\right)$ increased in small neurons isolated from murine L3-L6 DRGs ipsilateral to fibrosarcoma cell tumors. The increased responses were associated with increased mRNA levels for the $\mathrm{Ca}^{2+}$ channel subunit $\alpha 2 \delta 1$ and TRPV1 receptor. Pretreatment with gabapentin, an inhibitor of the $\alpha 2 \delta 1$ subunit, blocked the increased response to $\mathrm{KCl}$ in vitro and the mechanical hyperalgesia in tumor-bearing mice in vivo. Similar increases in neuronal responsiveness occurred when DRG neurons from naive mice and fibrosarcoma cells were cocultured for $48 \mathrm{~h}$. The CC chemokine ligand 2 (CCL2) may contribute to the tumor cell-induced sensitization because CCL2 immunoreactivity was present in tumors, high levels of CCL2 peptide were present in microperfusates from tumors, and treatment of DRG neurons in vitro with CCL2 increased the amount of mRNA for the $\alpha 2 \delta 1$ subunit. Together, our data provide strong evidence that the chemical mediator CCL2 is released from tumor cells and evokes phenotypic changes in sensory neurons, including increases in voltage-gated Ca ${ }^{2+}$ channels that likely underlie the mechanical hyperalgesia in the fibrosarcoma cancer model. More broadly, this study provides a novel in vitro model to resolve the cellular and molecular mechanisms by which tumor cells drive functional changes in nociceptors.

Key words: calcium; capsaicin; channel; culture; dorsal root ganglion; receptor; TRPV

\section{Introduction}

Pain is the most persistent and incapacitating symptom associated with bone cancer (Mercadante, 1997). Experimental models of cancer pain have shown that osteolytic tumor growth can result in the sensitization of C-fiber nociceptors (Cain et al., 2001) and dorsal horn neurons (Urch et al., 2003). Mechanisms underlying cancer pain include some components common to inflammatory and neuropathic pain (Brant, 1998; Wacnik et al., 2003); however, Honore et al. (2000) have suggested that there are mechanisms unique to tumor-evoked nociception, including the release of peptides from tumor cells and their direct effect on sensory neurons. The nature and consequences of direct chemical interactions between cancer cells and dorsal root ganglion (DRG) neurons that contribute to pain are difficult to study in

Received March 1, 2007; revised July 31, 2007; accepted Aug. 8, 2007.

This work was supported by National Institutes of Health Grants DA11471, CA091007 (D.A.S.), NS40538 (C.L.S.), and CA084233 (A.J.B.) and by the Academic Health (enter of the University of Minnesota. We thank Kate Merath, Chris Steevens, and Bryan Seybold for technical assistance and J. Hodges for invaluable statistical support.

Correspondence should be addressed to Dr. Virginia S. Seybold, Department of Neuroscience, University of Minnesota, 6-145 Jackson Hall, 321 Church Street, Southeast, Minneapolis, MN 55455. E-mail: vseybold@umn.edu.

L. Eikmeier's present address: Department of Veterinary Population Medicine, University of Minnesota, St. Paul, MN 55108.

DOI:10.1523/JNEUROSCI.2851-07.2007

Copyright $\odot 2007$ Society for Neuroscience 0270-6474/07/2710289-10\$15.00/0 vivo because multiple factors contribute to tumor-related pain. To examine the humoral effects of cancer cells on the response properties of nociceptive neurons, we developed a novel in vitro model wherein DRG neurons were cocultured with cancer cells and subsequently studied with functional and morphological approaches.

Chemokines are proinflammatory cytokines that have been implicated in the development and maintenance of pain (Abbadie, 2005). The CC chemokine ligand 2 (CCL2) may be a mediator of phenotypic changes in DRG neurons in cancer pain because CCL2 has been identified in human fibrosarcoma cell lines (Zachariae et al., 1990; Ueda et al., 1994) and DRG neurons express two receptors activated by CCL2: CC chemokine receptor 2 (CCR2) and CCR4 (Oh et al., 2001; White et al., 2005). Three lines of evidence suggest CCL2 is a mediator of persistent hyperalgesia. First, CCL2 depolarizes DRG neurons in models of neuropathic pain, and, second, CCL2 and CCR2 receptors are upregulated in injured neurons (White et al., 2005; Sun et al., 2006). Finally, the development of mechanical allodynia is blocked in a model of neuropathic pain in CCR2 knock-out mice (Abbadie et al., 2003).

Evoked $\mathrm{Ca}^{2+}$ transients are a bioassay for functional responses of small DRG neurons to chemical stimuli. The occurrence of a $\mathrm{Ca}^{2+}$ transient in DRG neurons is directly related to 
activation of voltage-dependent $\mathrm{Ca}^{2+}$ channels after neuronal excitation (Thayer and Miller, 1990; Ruscheweyh and Sandkuhler, 2005). The $\mathrm{Ca}^{2+}$ channel subunit $\alpha 2 \delta 1$ regulates the density of voltage-dependent $\mathrm{Ca}^{2+}$ channels in the membrane as well as channel opening (Gurnett CA et al., 1996; Walker and De Waard, 1998). It is noteworthy that increased expression of the $\alpha 2 \delta 1$ subunit in DRG neurons has been linked to neuropathic pain (Luo et al., 2001; Newton et al., 2001). A Ca ${ }^{2+}$ transient is also evoked after chemical activation of the nonselective cation channels TRPV1 (Caterina and Julius, 2001) and P2X receptors (He et al., 2003).

Thus, we used multiple, parallel in vivo and in vitro approaches to determine the mechanisms by which cancer cells affect the function of nociceptors, including behavioral, cellular, and molecular analyses. One important scheme was the development of a novel coculture model that allowed us to determine at a cellular level whether factors released by cancer cells directly alter the functional properties of DRG neurons. The fact that we obtained comparable results in experiments using the coculture model and tumor-bearing mice is evidence of the strong potential of exploiting a coculture model to study mechanisms underlying the effects of cancer cells on sensory neuron function.

\section{Materials and Methods}

Animals. Adult, male $\mathrm{C} 3 \mathrm{H} / \mathrm{He}$ mice (National Cancer Institute, Bethesda, MD; 25-30 g) were used in the studies. This strain is syngeneic to the fibrosarcoma cells used in the experiments and allows the fibrosarcoma cells to grow tumors without rejection (Clohisy et al., 1996). Tumors were generated in some mice by injecting fibrosarcoma cells $(2 \times$ $10^{5}$ ) in $10 \mu \mathrm{l}$ of PBS, pH 7.3, unilaterally into and around the calcaneus bone under halothane anesthesia as described previously (Cain et al., 2001; Wacnik et al., 2001). All procedures were approved by the University of Minnesota Institutional Animal Care and Use Committee.

Assessment of mechanical hyperalgesia. Animals were placed on a wire mesh platform and allowed to acclimate to their surroundings for a minimum of $30 \mathrm{~min}$ before testing. A von Frey monofilament with a bending force of $3.4 \mathrm{mN}$ was applied 10 times to the plantar surface of each hindpaw. The number of vigorous responses to the monofilament was counted, and the result is expressed as the percentage of stimuli giving rise to a response. Initially, mice were prescreened for hypersensitivity to this stimulus, and animals with responses $\geq 50 \%$ were removed from further experimentation ( $<5 \%$ of mice) (Wacnik et al., 2001). Baseline values for mechanical sensitivity were subsequently determined for each animal for $3 \mathrm{~d}$ before tumor implantation and for $10 \mathrm{~d}$ after tumor implantation to monitor tumor development. Only mice exhibiting mechanical hyperalgesia ( $\geq 70 \%$ frequency of withdrawal to a force of $3.4 \mathrm{mN}$ applied to the plantar surface of the ipsilateral hindpaw) were used for the group defined as "tumor bearing."

Preparation of isolated adult murine DRG neurons. Primary cultures of dissociated DRGs from tumor-bearing mice were limited to the L3-L6 DRGs ipsilateral to the tumor. Control cultures were prepared from L3-L6 DRGs of naive mice. Cultures of DRGs were prepared as described previously with slight modifications (Scott, 1977). After enzymatic and mechanical dissociation, the final cell suspension was plated at a density of 10,000 cells $/ 25 \mathrm{~mm}^{2}$ on laminin-coated glass coverslips (Fisher Scientific, Pittsburgh, PA) and maintained in Ham's F-12/DMEM supplemented with L-glutamine $(2 \mathrm{~mm})$, glucose $(40 \mathrm{~mm})$, penicillin $(100$ $\mathrm{U} / \mathrm{ml})$, streptomycin $(100 \mu \mathrm{g} / \mathrm{ml}), 5 \%$ horse serum, and DNAase I $(0.15$ $\mathrm{mg} / \mathrm{ml}$; Sigma, St. Louis, MO). Cells were placed in a humidified atmosphere of $5 \% \mathrm{CO}_{2}$ at $37^{\circ} \mathrm{C}$ for $16-24 \mathrm{~h}$ before use. DRG neurons used in the coculture model were routinely prepared from ganglia dissected from all levels of the spinal cord of naive adult male mice.

Noncontact cocultures. The murine NCTC clone 2472 fibrosarcoma cell line (American Type Culture Collection, Manassas, VA) was maintained in NCTC 135 medium as described previously (Clohisy et al., 1996). Three days before preparation of cocultures, fibrosarcoma cells were harvested, rinsed with PBS, pH 7.4, and plated at a density of 50,000 cells/150 $\mu \mathrm{l} / 25 \mathrm{~mm}^{2}$ on glass coverslips (Fisher Scientific). Cells were maintained in DRG medium (minus the DNAase) in a humidified atmosphere of $5 \% \mathrm{CO}_{2}$ at $37^{\circ} \mathrm{C}$. On the day of DRG isolation, a coverslip with freshly isolated neurons was combined in one Petri dish with a coverslip of preplated fibrosarcoma cells. Cells were maintained in $3 \mathrm{ml}$ of fresh Ham's F-12/DMEM plus $2 \mathrm{ml}$ of fibrosarcoma cell-conditioned medium at $37^{\circ} \mathrm{C}$ in a humidified atmosphere of $5 \% \mathrm{CO}_{2}$. Neurons were maintained in vitro for $40-48 \mathrm{~h}$ before use. No physical contact occurred between neurons and fibrosarcoma cells during this time.

Because fibrosarcoma cells in the coculture condition were maintained in DRG medium and not the medium routinely used to prepare cells for implantation in vivo, we tested whether the change in medium altered their ability to produce hyperalgesia. After fibrosarcoma cells were grown for $5 \mathrm{~d}$ in the DRG medium (Ham's F-12/DMEM with supplements) and injected into mice, tumors indeed formed and produced mechanical hyperalgesia that was comparable to when the cancer cells were maintained in the NCTC 135 medium.

Measurement of free intracellular calcium concentration $\left(\left[\mathrm{Ca}^{2+}\right]_{i}\right)$. Measures of $\left[\mathrm{Ca}^{2+}\right]_{\mathrm{i}}$ were made in the somata of single neurons at $22-$ $24^{\circ} \mathrm{C}$. A dual-emission microfluorimeter (Photoscan; Photon Technology International, Princeton, NJ) was used to monitor fluorescence of indo-1 ( $3 \mu \mathrm{M}$; Invitrogen, Eugene, OR) as described previously in our laboratory (Khasabova et al., 2002). Some data for responses to ATP were acquired by $\mathrm{Ca}^{2+}$ imaging in which the Fura- 2 ratio was measured in neurons loaded with the $\mathrm{Ca}^{2+}$ indicator Fura-2 AM (Invitrogen, Carlsbad, CA) as described previously by others (Thut et al., 2003). Regardless of the approach, only one field of neurons was recorded from each coverslip. The maximum and minimum diameters of each neuron were estimated using a grid mounted in the eyepiece of the microscope. These values were used to calculate the average radius that was used to calculate the somal cross-sectional area using the equation area $=\pi r^{2}$. Although the experimenters were not blinded to the treatment of the DRG neurons when selecting neurons for measures of intracellular $\mathrm{Ca}^{2+}$, there were no differences in the mean sizes of neurons sampled for treatments within each experimental paradigm $(p=0.894$ for data after $24 \mathrm{~h}$ in vitro; $p=$ 0.103 for data after $48 \mathrm{~h}$ in vitro; one-way ANOVA across all treatments groups within each duration of culture). These data are evidence of unbiased sampling across treatment groups as well as consistency in sampling of isolated neurons.

After confirmation of a stable baseline in $\left[\mathrm{Ca}^{2+}\right]_{\mathrm{i}}$, changes in functional properties of DRG neurons were defined by the occurrence of a $\mathrm{Ca}^{2+}$ transient in response to superfusion with $\mathrm{KCl}(25 \mathrm{~mm}, 10 \mathrm{~s})$, capsaicin ( $500 \mathrm{~nm}, 30 \mathrm{~s}$ ), or ATP (1 nм to $20 \mu \mathrm{M}, 30 \mathrm{~s}$ ). One test substance was applied per neuron unless otherwise indicated. Viability of neurons was confirmed by superfusion with $\mathrm{KCl}(50 \mathrm{~mm}, 10 \mathrm{~s}) 5 \mathrm{~min}$ after application of the test substance, and only neurons that responded to $50 \mathrm{~mm} \mathrm{KCl}$ were included in the data set. Because fewer neurons were isolated from DRGs in tumor-bearing mice, $\mathrm{KCl}(25 \mathrm{~mm})$, capsaicin, and $\mathrm{KCl}$ (50 mM) were applied sequentially at $5 \mathrm{~min}$ intervals. Preliminary studies demonstrated that the previous application of $25 \mathrm{~mm} \mathrm{KCl}$ did not affect the frequency or the amplitude of the response to capsaicin in neurons maintained in either the control or coculture conditions. The threshold for defining a positive response to chemical stimuli was an increase in $\left[\mathrm{Ca}^{2+}\right]_{\mathrm{i}}$ that was $>50 \%$ above baseline. The duration of a Ca ${ }^{2+}$ transient was defined as the interval of time during which the increase in $\left[\mathrm{Ca}^{2+}\right]_{\mathrm{i}}$ exceeded $110 \%$ of the baseline.

Quantification of $m R N A$ by real-time PCR. L3-L4 DRGs were isolated from mice, placed in RNAlater (Qiagen, Valencia, CA), and stored at $4^{\circ} \mathrm{C}$. Total RNA was isolated from the samples using RNeasy Lipid Tissue Mini kits (Qiagen) and reverse transcribed into cDNA using QuantiTect RT-PCR kits (Qiagen), as per the manufacturer's instructions. Real-time PCR studies were performed with DyNAmo HS SYBR Green Master Mix (Finnzymes, Keilaranta, Finland) using the DNA engine Opticon 2 (MJ Research, Waterton, MA) through $45 \mathrm{PCR}$ cycles $\left(94^{\circ} \mathrm{C}\right.$ for $10 \mathrm{~s}, 57-59^{\circ} \mathrm{C}$ for $20 \mathrm{~s}$, and $72^{\circ} \mathrm{C}$ for $30 \mathrm{~s}$ ). Each cDNA sample, equivalent to RNA from L3-L4 DRGs on one side of the mouse, was run in triplicate for the murine calcium channel subunit $\alpha 2 \delta 1$, TRPV1, and the reference gene (S15). S15 was chosen as the reference gene because its expression did not change relative to experimental conditions. Primer pair sequences were 
as follows: murine calcium channel subunit $\alpha 2 \delta 1$ (GenBank accession number NM_009784), forward primer 5'-GAT CCT TGC GAC ATG GTC AAG-3' (nucleotides 3297-3317) and reverse primer 5' -CCC AGA AAC ACC ACC ACA GTC-3' (3381-3401); TRPV1 (GenBank accession number AY445519), forward primer 5'-GGC TTC CAT GGT GTT CTC CC-3' (1617-1636) and reverse primer 5'-CCG ACA CAG GTC TCT GAG GA-3' (1721-1740); S15 (BC094409), forward primer 5'-CCG AAG TGG AGC AGA AGA AG-3' (20-39) and reverse primer 5'-CTC CAC CTG GTT GAA GGT C-3' (315-333). All primers were synthesized by Operon Biotechnologies (Germantown, MD). Specificity of amplicons was confirmed by melting curve analysis, evidence of a single band after gel electrophoresis, authenticity of the DNA sequence of the band isolated from the gel, and resolution by BLAST (Basic Local Alignment Search Tool) analysis that the sequences of the amplicons were unique to murine calcium channel subunit $\alpha 2 \delta 1$, TRPV1, and S15, respectively.

The ratio of fold change in expression of the mRNA of interest for each sample was calculated by normalization of cycle threshold $(\mathrm{Ct})$ values to S15 using the equation derived by Pfaffl (2001) to correct for potential differences in PCR primer efficiencies between the target and reference genes. This approach was validated by the lack of an effect of treatments on the expression of $S 15$ and confirmed that data for tissue samples were within the linear range used to determine the efficiency of the primers. The efficiency of the primer set was derived from the slope of the linear regression of $\mathrm{Ct}$ and sample dilution using the equation: efficiency $=$ $10^{(-1 / \text { Slope })}$. Samples were collected from normal and tumor-bearing mice four times. To control for variability in preparations and assays, data for calcium channel subunit $\alpha 2 \delta 1$ and TRPV 1 mRNA (corrected to the reference gene) were normalized to the mean of the control group for each date of sample collection.

Immunocytochemical studies. Immunocytochemistry on isolated DRG neurons was performed as described previously (Khasabova et al., 2002) to define the occurrence of TRPV1-immunoreactivity (ir) associated with neurons that were maintained in vitro for $40 \mathrm{~h}$. Cells were fixed with $4 \%$ paraformaldehyde in PBS for $30 \mathrm{~min}$ at room temperature before immunostaining. Guinea pig anti-TRPV1 receptor (1:1000; a gift from R. Elde, University of Minnesota, Minneapolis, MN) was diluted in PBS containing $0.1 \%$ sodium azide, $0.3 \%$ Triton X-100, and $5 \%$ normal donkey serum (Jackson ImmunoResearch, West Grove, PA). To confirm the association of TRPV1-ir with neurons, double labeling was performed by combining the TRPV1 antibody with mouse anti-NeuN antibody (1:100; Chemicon, Temecula, CA) that binds a neuron-specific nuclear protein. Primary antibodies were differentially detected with tetramethylrhodamine isothiocyanate-labeled donkey anti-guinea pig $\operatorname{IgG}(1: 100)$ and 7-amino-4-methylcoumarin-3-acetic acid-labeled donkey anti-mouse IgG (1:100; Jackson ImmunoResearch). Incubation of each diluted antibody with its respective immunogen $(10 \mu \mathrm{g} / \mathrm{ml})$ blocked immunofluorescence, indicating that the antibodies were specific for the expected antigen. In addition, no immunofluorescence was seen in the absence of primary antibodies. Fluorescent markers were visualized differentially on a Nikon (Tokyo, Japan) E400 fluorescence microscope using a $10 \times$ or $20 \times$ fluorite objective, and digitized images were obtained with an MTI camera. Somal size and fluorescence were quantified by an observer who was blinded to the treatment of the samples. The cross-sectional area of the soma of neurons was determined by tracing the plasma membrane. Intensity of fluorescence was calculated for the area of the whole soma. A neuron was scored "immunopositive" if its average intensity was $>2$ SDs above the mean intensity of neurons labeled with the secondary antibody alone. This strategy was consistent with values determined by a naive observer who quantified immunofluorescence in neurons judged independently to be labeled by the primary antibodies.

CCL2 was visualized in tumors by immunoperoxidase histochemistry. At $10 \mathrm{~d}$ after implantation of fibrosarcoma cells, five mice were perfused transcardially with $15 \mathrm{ml}$ of PBS followed by $30 \mathrm{ml}$ of $4 \%$ paraformaldehyde in PBS. Tumors were harvested, cryoprotected in $20 \%$ sucrose, and sectioned at $40 \mu \mathrm{m}$ on a sliding microtome. The sections were preincubated with antibody diluent ( $2 \%$ rabbit serum in $0.3 \%$ Triton X-100) for $1 \mathrm{~h}$ and incubated overnight with mouse-specific goat anti-CCL2 antibody (dilution, 5-15 $\mu \mathrm{g} / \mathrm{ml}$; R \& D Systems, Minneapolis, MN). Sections were then incubated for $2 \mathrm{~h}$ with a biotinylated rabbit anti-goat second- ary antibody (1:250) and for $1 \mathrm{~h}$ with the $\mathrm{ABC}$ complex (1:50; Vector Laboratories, Burlingame, CA). Finally, sections were incubated with $0.05 \%$ diaminobenzidine, and the peroxidase reaction product was visualized using bright-field microscopy. Two controls suggest that the immunostaining was specific for CCL2-ir: no reaction product was generated when the diluted CCL2 antiserum was preincubated with $10 \mu \mathrm{M}$ CCL2 for $24 \mathrm{~h}$ at $4^{\circ} \mathrm{C}$ or when diluent alone was substituted for the CCL2 antibody.

Quantification of CCL2. CCL2 was quantified in tumor homogenates and in tumor perfusates. For tumor content, mice with fibrosarcoma tumors were deeply anesthetized with isoflurane, both hindlimbs were surgically removed, and the mice were immediately killed. The tumor and a comparable area of the contralateral hindpaw were carefully dissected from around the calcaneus bone, immediately frozen in liquid nitrogen, and stored as separate samples at $-80^{\circ} \mathrm{C}$ until processing. Tissue suspensions were made by finely mincing samples in $300 \mu \mathrm{l}$ of icecold PBS containing $0.4 \mathrm{M} \mathrm{NaCl}, 0.05 \%$ Tween $20,0.5 \% \mathrm{NGS}, 0.1 \mathrm{~mm}$ phenylmethylsulfonyl fluoride, $0.1 \mathrm{~mm}$ benzethonium chloride, $10 \mathrm{~mm}$ EDTA, and $1 \%$ protease inhibitor mixture (Sigma), and suspensions were ground with a disposable pestle (Fisher Scientific). Homogenized samples were centrifuged at $15,860 \times g$ for $30 \mathrm{~min}$ at $4^{\circ} \mathrm{C}$, and CCL2 was measured in the supernatant. Total protein content was determined using Coomassie Plus Protein Assay (Pierce, Rockford, IL).

A "push/pull" microperfusion system was used to collect extracellular fluid at the tumor site in vivo, as described previously (Wacnik et al., 2001). After induction of anesthesia, a microprobe was inserted into the center of the tumor site or into a comparable area of the hindpaw of naive mice and secured to the skin. Modified Ringer's buffer was perfused through the probe and collected at a rate of $10 \mu \mathrm{l} / \mathrm{min}$ (Wacnik et al., 2001). After a $45 \mathrm{~min}$ equilibration period, $750 \mu \mathrm{l}$ of microperfusate samples were collected over a period of $3-4 \mathrm{~h}$ and maintained at $4^{\circ} \mathrm{C}$. Protease inhibitor mixture (Sigma) was added to each sample to a final concentration of $1 \%$, and samples were stored at $-80^{\circ} \mathrm{C}$ for later analysis.

CCL2 levels were measured with a cytometric bead array, according to the manufacturer's instructions (CBA, Mouse Inflammatory Cytokine Bead Array; BD Biosciences, San Jose, CA). This system is analogous to a sandwich ELISA in a bead-based format in which fluorescence is measured by a flow cytometer. The recombinant murine CCL2 standards $(20-5000 \mathrm{pg} / \mathrm{ml})$ and each sample $(250 \mu \mathrm{g}$ of total protein for tissue homogenates or $100 \mu \mathrm{l}$ of microperfusate) were incubated with beads coated with a capture antibody and a second detection antibody conjugated to phycoerythrin in an assay volume of $150 \mu$ l. Fluorescence intensity of each sample was acquired using a flow cytometer. Data were analyzed using BD CBA Analysis software; the limit of detection was 52.7 $\mathrm{pg} / \mathrm{ml}$. To minimize variability, CCL2 was measured in all samples from tumor homogenates in one assay and in all samples for microperfusates in another iteration of the assay. Values for tumor homogenates are expressed as nanograms of CCL2 per gram of protein; values for microperfusates are expressed as nanograms of CCL2 per milliliter.

Drugs. Stock solutions of the vanilloid receptor agonist capsaicin (10 mM; Fluka, Buchs, Switzerland) were prepared in ethanol. All chemicals were diluted in the HEPES buffer to the final concentrations indicated for superfusion. Solutions of gabapentin $(10 \mu \mathrm{g} / \mu \mathrm{l})$, lidocaine $(1 \mathrm{~mm})$, and adenosine $5^{\prime}$-triphosphate $(20 \mu \mathrm{M})$ were prepared on the day of the experiment from materials purchased from Sigma-Aldrich (St. Louis, $\mathrm{MO}$ ). Superfusion with any vehicle by itself at the highest concentration used with a drug did not alter basal or KCl-evoked increases in $\left[\mathrm{Ca}^{2+}\right]_{\mathrm{i}}$. Recombinant mouse CCL2 (MCP-1) was purchased from R \& D Systems.

Statistical analyses. Data are presented as the percentage of neurons responding or mean \pm SEM for each group. In measures of $\mathrm{Ca}^{2+}$ transients, statistical differences among groups were identified using Student's $t$ test or ANOVA followed by the Tukey's multiple comparisons test. In some instances, data were transformed to $\log _{10}$ before conducting an analysis to meet the normality requirement (Kolmogorov-Smirnov test; SigmaStat; Systat Software, San Jose, CA). The Fisher's exact test was used to determine differences in proportions of neurons exhibiting a trait or response. Homogenates and microperfusion data were analyzed by Student's $t$ test. Behavioral data were analyzed by two-way ANOVA for 
repeated measures and the Tukey's multiple comparisons test. A value of $p<0.05$ was considered significant. In vitro data for each treatment were collected from a minimum of three preparations from different animals. Data for control and treatment groups were determined on each day of an experiment to control for variation among preparations of neurons.

\section{Results}

Within $10 \mathrm{~d}$ after implantation of fibrosarcoma cells in and around the calcaneus bone, tumor-bearing mice exhibit mechanical hyperalgesia in the hindpaw ipsilateral to the tumor. Electrophysiological recordings from $\mathrm{C}$-fibers in these mice suggest that sensitization of small-diameter C-fibers contributes to cancer pain and tumorevoked hyperalgesia (Cain et al., 2001; Shimoyama et al., 2002). Because DRG neurons with cell bodies $<500 \mu \mathrm{m}^{2}$ give rise to C-fibers with a variety of nociceptor properties (Hiura and Sakamoto, 1987; Urban and Dray, 1993; Pearce and Duchen, 1994; Dirajlal et al., 2003), DRG neurons with somal areas $<500 \mu \mathrm{m}^{2}$ were selected for study and are referred to as small in this report.

\section{DRG neurons associated with tumors in vivo exhibited increases in intracellular $\mathrm{Ca}^{2+}$ signaling}

Small neurons isolated from L3-L6 DRGs ipsilateral to tumors in tumor-bearing mice exhibited changes in calcium homeostasis compared with small neurons isolated from L3-L6 DRGs of naive mice (Table 1). Initial observations were that the basal $\left[\mathrm{Ca}^{2+}\right]_{\mathrm{i}}$ was elevated in DRG neurons associated with tumors and $\mathrm{Ca}^{2+}$ transients evoked by $50 \mathrm{~mm} \mathrm{KCl}$ were greater. Changes in $\mathrm{Ca}^{2+}$ transients included a 76\% higher amplitude and a 76\% longer duration (i.e., time to recovery to baseline) compared with small neurons isolated from L3-L6 DRGs of naive mice. A variety of intracellular pathways contribute to the shape of $\mathrm{Ca}^{2+}$ transients, making it difficult to interpret changes in amplitude and duration (see Discussion). Therefore, subsequent results focus on the occurrence of a $\mathrm{Ca}^{2+}$ transient in response to chemical stimuli.

Because $50 \mathrm{mM} \mathrm{KCl}$ is a maximal stimulus for activation of voltage-dependent $\mathrm{Ca}^{2+}$ channels in DRG neurons, a concentration of $25 \mathrm{~mm} \mathrm{KCl}$ was used to estimate changes in voltagedependent $\mathrm{Ca}^{2+}$ channels. The amplitude of the $\mathrm{Ca}^{2+}$ transient evoked with $25 \mathrm{mM} \mathrm{KCl}$ in small DRG neurons from naive mice was at least $50 \%$ smaller $(97 \pm 7 \mathrm{nM} ; n=7)$ than the transient evoked by $50 \mathrm{~mm} \mathrm{KCl}$ (Table 1, Fig. $1 A$ ). Moreover, an increase in $\left[\mathrm{Ca}^{2+}\right]_{\mathrm{i}}$ of $>50 \%$ above baseline in response to brief superfusion with $50 \mathrm{~mm} \mathrm{KCl}$ was used to verify neuronal viability, but superfusion with $25 \mathrm{~mm} \mathrm{KCl}$ evoked a $\mathrm{Ca}^{2+}$ transient in only $19 \%$ of small neurons isolated from naive mice (Fig. 1, average of $B$ and $D)$. In contrast, small neurons isolated from DRGs associated with tumors were three times more likely to exhibit a $\mathrm{Ca}^{2+}$ transient in response to $25 \mathrm{~mm} \mathrm{KCl}$, suggesting increased activation of voltage-dependent $\mathrm{Ca}^{2+}$ channels (Fig. $1 B$ ).

Increased expression of the $\mathrm{Ca}^{2+}$ channel subunit $\alpha 2 \delta 1$ has been linked to hyperalgesia in models of neuropathic pain (Luo et al., 2001; Newton et al., 2001) and could contribute to the increased occurrence of a $\mathrm{Ca}^{2+}$ transient in response to $25 \mathrm{mM} \mathrm{KCl}$ in neurons isolated from tumor-bearing mice. Using quantitative reverse transcriptase-PCR, we determined that the mRNA for the murine $\mathrm{Ca}^{2+}$ channel subunit $\alpha 2 \delta 1$ was increased approximately twofold in L3-L4 DRGs ipsilateral to tumors in tumor-bearing mice compared with naive mice (Fig. 1C). Because gabapentin binds to the $\mathrm{Ca}^{2+}$ channel subunit $\alpha 2 \delta 1$, thereby blocking its activity (Wang et al., 1999), we predicted that gabapentin would decrease the response of small DRG neurons from tumor-bearing mice to $25 \mathrm{~mm} \mathrm{KCl}$ if the increased level of mRNA was associated with increased expression of the $\alpha 2 \delta 1$ subunit. Superfusion of neurons with gabapentin $(100 \mu \mathrm{M}, 5 \mathrm{~min})$ before $25 \mathrm{mM} \mathrm{KCl}$ had no effect on neurons from naive mice, but gabapentin blocked the enhanced response of small neurons from tumor-bearing mice to the same stimulus (Fig. 1D). The concentration of gabapentin was chosen based on its maximal effect in isolated murine DRG neurons ( $\mathrm{Li}$ et al., 2006). Together, the data on levels of mRNA for the $\mathrm{Ca}^{2+}$ channel subunit $\alpha 2 \delta 1$ and the functional data on inhibition with gabapentin suggest that the increased response to $25 \mathrm{~mm} \mathrm{KCl}$ in small DRG neurons from tumor-bearing mice was caused by facilitation of voltage-dependent $\mathrm{Ca}^{2+}$ channels.

\section{Gabapentin blocked mechanical hyperalgesia in vivo}

Given that gabapentin prevented the increased response to 25 $\mathrm{mM} \mathrm{KCl}$ in DRG neurons isolated from tumor-bearing mice in vitro, we tested its effect in vivo. On day 10 after implantation of fibrosarcoma cells, tumor-bearing mice exhibited mechanical hyperalgesia when tested with the $3.4 \mathrm{mN}$ microfilament on the plantar surface of the hindpaw ipsilateral to the tumor [Fig. 2, baseline (B)]. When gabapentin $(300 \mu \mathrm{g} / 30 \mu \mathrm{l})$ was injected subcutaneously into the plantar side of the hindpaw ipsilateral to the tumor, the mechanical hyperalgesia was blocked within 15 min of the injection, and the effect dissipated within $2 \mathrm{~h}$. A dose of 300 $\mu \mathrm{g}$ was chosen because it was the lowest effective dose in a pilot study. In contrast, the same dose of gabapentin had no effect compared with injection of the vehicle (saline) in naive mice. When considered in conjunction with the in vitro data on DRG neurons, it is likely that an increased activation of voltagedependent calcium channels contributed to the mechanical hyperalgesia observed in tumor-bearing mice.

\section{DRG neurons from tumor-bearing mice exhibited increased responses to capsaicin}

An increased response to capsaicin paralleled the increased response to $25 \mathrm{~mm} \mathrm{KCl}$ in small neurons isolated from tumor-bearing mice. Two-thirds more small DRG neurons isolated from tumor-bearing mice responded to capsaicin ( $500 \mathrm{nM}$ ) compared with DRG neurons from naive mice (Fig. $3 A$ ). The enhanced response to capsaicin was accompanied by a $75 \%$ increase in the amount of mRNA for the murine TRPV1 receptor (Fig. 3B).

Functional changes in DRG neurons from tumor-bearing mice were reproduced by coculturing DRG neurons from naive mice with fibrosarcoma cells

Studies of DRG neurons associated with tumors are limited by the small number of affected neurons. To increase availability of 
A

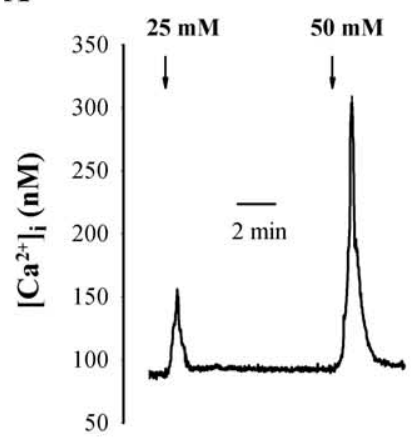

B

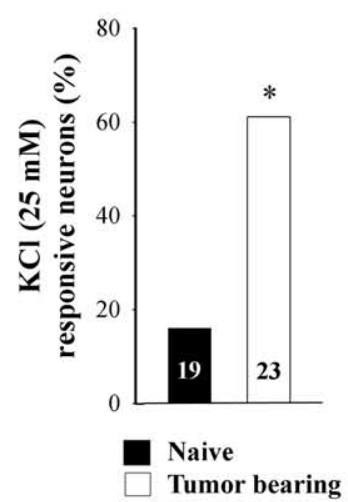

C

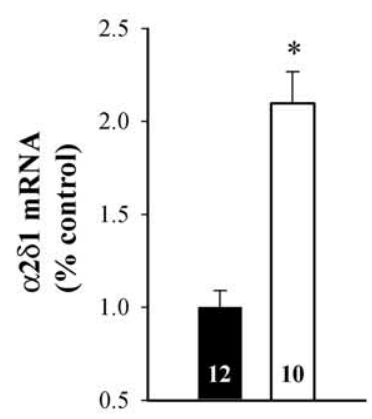

D

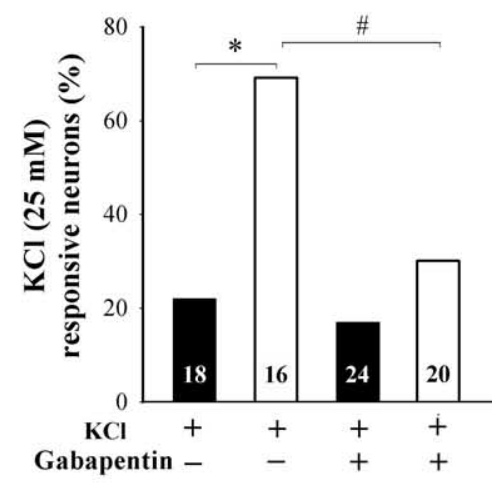

Figure 1. Increased expression of the $\mathrm{Ca}^{2+}$ channel subunit $\alpha 2 \delta 1$ contributed to the increased occurrence of $\mathrm{Ca}^{2+}$ transients in small neurons from $\mathrm{L} 3-\mathrm{L} 6 \mathrm{DRGs}$ ipsilateral to tumors in tumor-bearing mice. DRGs were isolated from tumor-bearing mice $10 \mathrm{~d}$ after implantation of tumors and maintained in vitro for $16-24 \mathrm{~h}$. L3-L4 DRGs from naive mice were used as controls. Ca ${ }^{2+}$ transients were evoked in small neurons (somal areas $<500 \mu \mathrm{m}^{2}$ ) by superfusion with $25 \mathrm{~mm} \mathrm{KCl}(10 \mathrm{~s})$ unless otherwise noted. $A$, Representative trace of $\mathrm{Ca}^{2+}$ transients evoked in a small neuron from a naive mouse. Arrows indicate superfusion with $\mathrm{KCl}$. The amplitude of the transient evoked by $25 \mathrm{~mm} \mathrm{KCl}$ was less than one-half of that evoked by the supramaximal stimulus $50 \mathrm{~mm} \mathrm{KCl}$ used to confirm viable neurons. $\boldsymbol{B}, \mathrm{A}$ larger proportion of small neurons from tumor-bearing mice responded with a $\mathrm{Ca}^{2+}$ transient after superfusion with $25 \mathrm{~mm} \mathrm{KCl}$ compared with naive mice. The threshold for defining a positive response was an increase in $\left[\mathrm{Ca}^{2+}\right]_{\mathrm{i}}$ that was $>50 \%$ of baseline. ${ }^{*}$ Significantly different from the naive group at $p<0.005$ (Fisher's exact test). $C$, The increased occurrence of a $\mathrm{Ca}^{2+}$ transient in tumor-bearing mice was associated with an increase in the level of mRNA for the $\mathrm{Ca}^{2+}$ channel subunit $\alpha 2 \delta 1$. Quantitative reverse transcriptase-PCR was used to measure mRNA in L3-L4 DRGs from naive mice or L3-L4 DRGs ipsilateral to tumors in tumor-bearing mice. Values for the target gene were normalized to a reference gene within each sample, and data were then normalized to the average for the naive group within each procedure for isolation of mRNA. Results are expressed as percentage of control. One sample was removed from the data set for tumor-bearing mice because the level of mRNA was $>2$ SDs above the mean for the group. ${ }^{*}$ Significantly different from the naive group at $p<0.001$ (Student's $t$ test). $\boldsymbol{D}$, Pretreatment with gabapentin $(100 \mu \mathrm{m}, 5 \mathrm{~min})$ had no effect on the occurrence of $\mathrm{Ca}^{2+}$ transients in neurons from naive mice but blocked the increase that was observed in neurons from tumor-bearing mice. *Significantly different naive mice and "different from control tumor-bearing mice at $p<0.05$ (Fisher's exact test). The sample size for each treatment group appears within each bar.

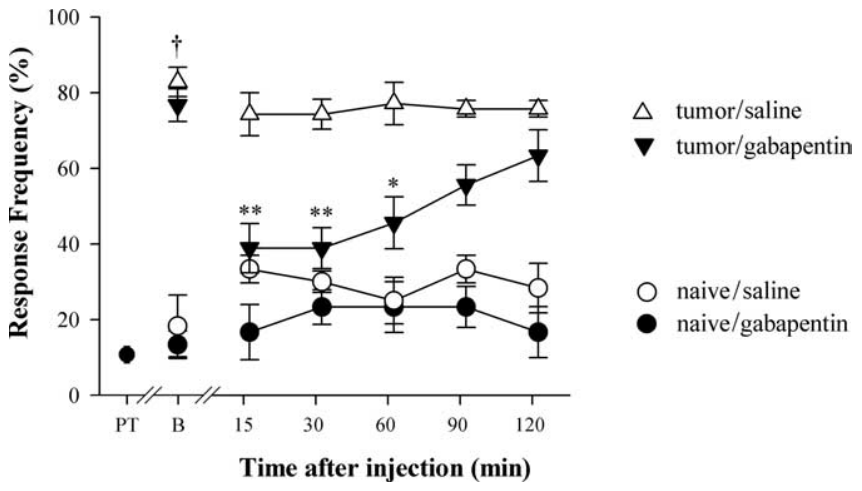

Figure 2. Gabapentin blocked the mechanical hyperalgesia in tumor-bearing mice. Responses to a $3.4 \mathrm{mN}$ monofilament were measured in the left hindpaw. The frequency of response increased in tumor-bearing mice (triangles) at $10 \mathrm{~d}$ after implantation of fibrosarcoma cells in and around the calcaneus bone of the left hindpaw compared with naive mice before injection of gabapentin (B, baseline) and pretumor (PT) responses of all mice. Mechanical hyperalgesia was blocked within 15 min of injection of $300 \mu \mathrm{g}$ of gabapentin into the left hindpaw, and the effect dissipated within $2 \mathrm{~h}$. Symbols are as follows: significantly different from the tumor/saline group at ${ }^{*} p<0.01$ and ${ }^{* *} p<0.001$; ${ }^{\dagger}$ different from control at $p<0.001$; two-way ANOVA with repeated measures with Tukey's post hoc test.

material in which to conduct functional and neurochemical studies and to determine whether changes observed in small DRG neurons isolated from tumor-bearing mice were attributable to direct effects of substances released from fibrosarcoma cells, we developed a novel in vitro model. The in vitro model is based on maintaining DRG neurons from naive mice and fibrosarcoma cells on separate coverslips in the same culture well for $40-48 \mathrm{~h}$. This coculture preparation did not impair the survival of either the neurons or the fibrosarcoma cells (see supplemental material, available at www.jneurosci.org). Furthermore, the distribution of neurons, defined by area of the soma, was identical between DRG neurons cultured alone and those cocultured with fibrosarcoma
A

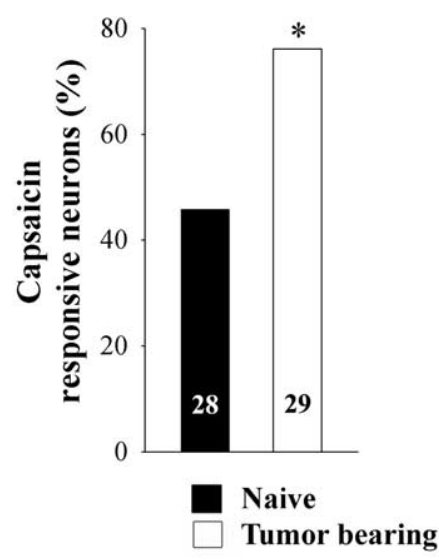

Figure 3. Capsaicin responsiveness increased in tumor-bearing mice. $A$, A larger proportion of small neurons responded with a $\mathrm{Ca}^{2+}$ transient after superfusion with $500 \mathrm{~nm}$ capsaicin. *Significantly different from naive mice at $p<0.05$ (Fisher's exact test). $\boldsymbol{B}$, The amount of mRNA for the murine TRPV1 receptor was greater in L3-L4 DRGs ipsilateral to tumors in tumorbearing mice compared with DRGs from the same levels of naive mice. Quantitative reverse transcriptase-PCR was used to measure $m R N A$, and values for the target gene were normalized to the reference gene $S 15$ within each sample. Data were then normalized to the average for the naive group within each procedure for isolation of $\mathrm{mRNA}$ and are expressed as percentage of control. * Significantly different from naive at $p<0.01$ (Student's $t$ test). The sample size for each treatment group appears within each bar.

cells (see supplemental material, available at www.jneurosci.org). Importantly, the distributions in both conditions are consistent with measurements obtained from sections through murine DRG (Zhong et al., 1999; Kerschensteiner et al., 2005).

Small DRG neurons cocultured with fibrosarcoma cells exhibited neurochemical alterations and changes in functional responses to chemical stimuli that are similar to those observed in DRG neurons isolated from tumor-bearing mice. First, small 
A

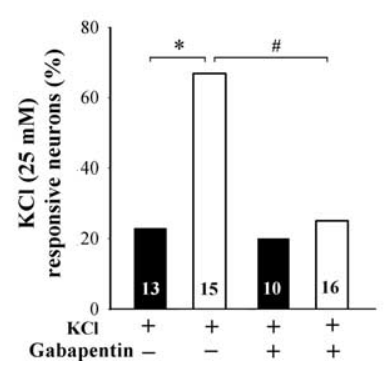

B

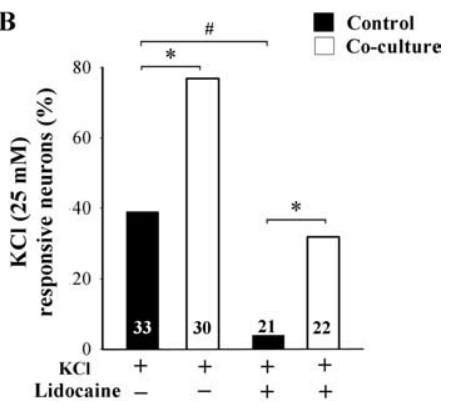

Figure 4. Coculture of DRG neurons with fibrosarcoma cells increased the proportion of neurons that responded with a $\mathrm{Ca}^{2+}$ transient after superfusion with $25 \mathrm{~mm} \mathrm{KCl}(10 \mathrm{~s})$. $\boldsymbol{A}$, Pretreatment with gabapentin ( $100 \mu \mathrm{M}, 5 \mathrm{~min}$ ) blocked the increased response to $25 \mathrm{~mm} \mathrm{KCl}$ in the coculture condition but had no effect on control neurons. *Significantly different from control at $p<0.05$; "different from the coculture control at $p<0.05$; Fisher's exact test. $\boldsymbol{B}$, Pretreatment with lidocaine $(1 \mathrm{~mm}, 10 \mathrm{~min})$ inhibited the occurrence of transients in response to $25 \mathrm{~mm} \mathrm{KCl}$ in control neurons, but the increased response in neurons from the coculture condition was maintained. *Significantly different from the same treatment group in the control culture at $p<0.05$; " significantly different from no drug at $p<0.01$; Fisher's exact test. Values inside the bars represent the sample size.

DRG neurons maintained in vitro with fibrosarcoma cells exhibited the same pattern of changes in $\left[\mathrm{Ca}^{2+}\right]_{i}$ homeostasis. These changes included increased basal $\left[\mathrm{Ca}^{2+}\right]_{\mathrm{i}}$ levels as well as a larger $\mathrm{Ca}^{2+}$ transient in response to depolarization with $50 \mathrm{mM} \mathrm{KCl}$ (Table 1). Second, twice as many small neurons from the coculture condition exhibited a $\mathrm{Ca}^{2+}$ transient in response to $25 \mathrm{mM}$ $\mathrm{KCl}$ compared with control neurons: $69 \%$ of neurons in the coculture condition compared with $35 \%$ in the control condition $(p<0.005$, Fisher's exact test) (combined data in the absence of drug from Fig. 4). Third, the increased occurrence of a $\mathrm{Ca}^{2+}$ transient in small neurons in response to $25 \mathrm{mM} \mathrm{KCl}$ was blocked by pretreatment with $\alpha 2 \delta 1$ subunit inhibitor gabapentin (100 $\mu \mathrm{M})$ (Fig. 4A). Therefore, small neurons maintained in vitro in the presence of fibrosarcoma cells exhibited the same changes in $\mathrm{Ca}^{2+}$ homeostasis and evoked transients as were observed in small neurons isolated from tumor-bearing mice.

Using the in vitro coculture model, we extended studies of the $\mathrm{Ca}^{2+}$ transient evoked by $25 \mathrm{~mm} \mathrm{KCl}$ to determine the contribution of voltage-dependent $\mathrm{Na}^{+}$channels to the response. When control neurons were pretreated with the nonselective $\mathrm{Na}^{+}$channel blocker lidocaine ( $1 \mathrm{~mm}, 10 \mathrm{~min}$ superfusion), only a small proportion of neurons (4\%) responded, suggesting that the $\mathrm{Ca}^{2+}$ transient evoked with $25 \mathrm{~mm} \mathrm{KCl}$ was essentially secondary to activation of voltage-dependent $\mathrm{Na}^{+}$channels. However, a much larger proportion (eightfold greater) of small DRG neurons cocultured with fibrosarcoma cells responded to $25 \mathrm{mM} \mathrm{KCl}$ in the presence of lidocaine, indicating that their response was independent of voltage-dependent $\mathrm{Na}^{2+}$ channels (Fig. 4B). These data provide further evidence that the activation of voltagedependent $\mathrm{Ca}^{2+}$ channels was enhanced in neurons maintained in medium conditioned by fibrosarcoma cells.

An increased response to capsaicin also occurred in DRG neurons cocultured with fibrosarcoma cells. In the control condition, $38 \%$ of small DRG neurons responded to a maximally effective concentration of capsaicin (500 nM) (Fig. 5A), which was consistent with the distribution of TRPV1 receptor-ir among small DRG neurons (35\%) (Fig. 5B). In the coculture condition, the proportion of small DRG neurons that responded to capsaicin increased to $>60 \%$, which was paralleled by an increase in the proportion of small neurons that exhibited TRPV1-ir (Fig. $5 B-D)$.

A different pattern of change was noted for responses to ATP. Across a range of $1 \mathrm{nM}$ to $1 \mu \mathrm{M}$ ATP, there were no differences between neurons in the control and coculture condition in the proportions of small neurons in which ATP evoked $\mathrm{Ca}^{2+}$ transients (15-50\% neurons responding within each group, $n=17-$ 111 neurons per concentration). In addition, there were no differences in the amplitudes of the $\mathrm{Ca}^{2+}$ transients (data not shown). However, the amplitude of the $\mathrm{Ca}^{2+}$ transient evoked with $20 \mu \mathrm{M}$ ATP was less in the coculture condition $(155 \pm 27 \mathrm{nM}$, $n=14$, compared with $481 \pm 127 \mathrm{nM}, n=13$, in the control; $p<$ 0.05 , Student's $t$ test), but there was no change in the frequency in which a response occurred (coculture condition, 43\%; control, $46 \%$ ). Overall, the excitability of ATP-gated channels, including P2X ionotropic and P2Y metabotropic receptors, in small DRG neurons was not altered by fibrosarcoma cells.

To test whether changes in functional responses to $25 \mathrm{~mm} \mathrm{KCl}$ and capsaicin reflected acute effects of fibrosarcoma cellconditioned medium on DRG neurons, DRG neurons maintained in vitro for $40-48 \mathrm{~h}$ under the control condition were incubated with fibrosarcoma cell-conditioned medium for $1 \mathrm{~h}$ before loading of indo-1. No change occurred in the percentage of small DRG neurons that responded to either $25 \mathrm{~mm} \mathrm{KCl} \mathrm{(35 \% ;}$ $n=26 ; p<0.79$, Fisher's exact test $)$ or capsaicin $(32 \% ; n=25$; $p<0.80$, Fisher's exact test). These data indicate that the changes in response properties observed in superfusion experiments are not based on the acute chemical modification of membrane proteins in response to mediators released from tumor cells.

\section{CCL2 effects on DRG neurons}

The persistence of the functional changes in small DRG neurons from tumor-bearing mice maintained alone in vitro for $16-24 \mathrm{~h}$ and the changes in mRNA for the $\mathrm{Ca}^{2+}$ channel subunit $\alpha 2 \delta 1$ and the TRPV1 receptor are evidence of phenotypic changes in sensory neurons of tumor-bearing mice. The ability to reproduce these functional changes with the coculture of DRG neurons and fibrosarcoma cells indicates that factors released from fibrosarcoma cells are sufficient to evoke the functional changes. We tested the hypothesis that CCL2 contributes to changes in gene expression in murine DRG neurons.

CCL2 was identified as a potential candidate because it is expressed by human fibrosarcoma cell lines and it is implicated in persistent pain. In the murine model of fibrosarcoma bone cancer, CCL2-ir occurred in tumors and was released by tumors in vivo. Three different approaches identified CCL2-ir in tumors. Immunohistochemical studies identified CCL2-ir in cells within tumors (Fig. 6A,B), and CCL2-ir was quantified in tumor homogenates using an immunoassay. Levels of CCL2-ir were 10fold greater in tumor homogenates compared with the same region in the contralateral hindpaw (Fig. 6C). In the third approach, 10-fold greater levels of CCL2-ir were recovered in microperfusates of tumors in vivo compared with microperfusates of the same region of naive mice (Fig. 6D) providing evidence that CCL2 was released in vivo. Therefore, we tested whether treatment of isolated DRG neurons with CCL2 altered gene expression in DRG neurons.

Primary cultures of DRG cells from naive mice were maintained in vitro for $40 \mathrm{~h}$ before the addition of CCL2 to a final concentration of $10 \mathrm{ng} / \mathrm{ml}(1.2 \mathrm{nM})$. The concentration of 10 $\mathrm{ng} / \mathrm{ml}$ was chosen because preliminary studies determined that this was the average concentration of CCL2-ir in the coculture condition after $48 \mathrm{~h}$ in vitro. CCL2 increased mRNA for the $\mathrm{Ca}^{2+}$ channel subunit $\alpha 2 \delta 1$ by $50 \%$ in the cultures after $2 \mathrm{~h}$ (Fig. $7 A$ ). A similar trend occurred in mRNA for the TRPV1 receptor (Fig. 


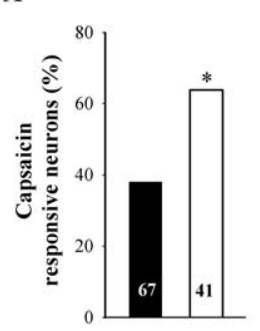

B

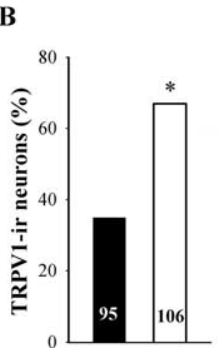

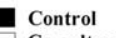

Control
Co-culture

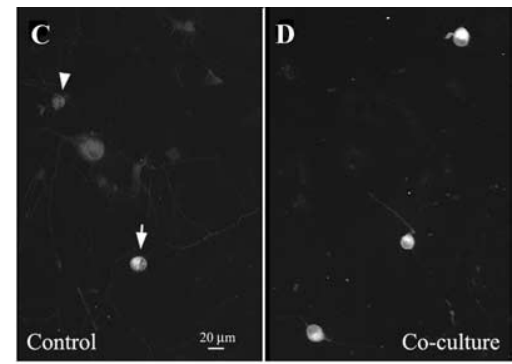

Figure 5. Capsaicin responsiveness increased in neurons cocultured with fibrosarcoma cells for $40-48 \mathrm{~h}$. $A$, Coculture of DRG neurons with fibrosarcoma cells increased the proportion of small neurons in which capsaicin $(500 \mathrm{~nm})$ evoked a $\mathrm{Ca}^{2+}$ transient. *Significantly different from control at $p<0.05$ (Fisher's exact test). $\boldsymbol{B}$, The increase in response to capsaicin was accompanied by an increase in the proportion of small neurons that exhibited TRPV1-ir. *Significantly different from control at $p<0.001$ (Fisher's exact test). Values inside the bars represent the sample size. $C, D$, Representative images, at the same magnification, of TRPV1 immunofluorescence in DRG neurons maintained in vitro for $48 \mathrm{~h}$ in the control $(\boldsymbol{C})$ and coculture $(\boldsymbol{D})$ conditions. In $\boldsymbol{C}$, The arrow designates a TRPV1-immunoreactive neuron, and the arrowhead indicates a nonlabeled neuron.
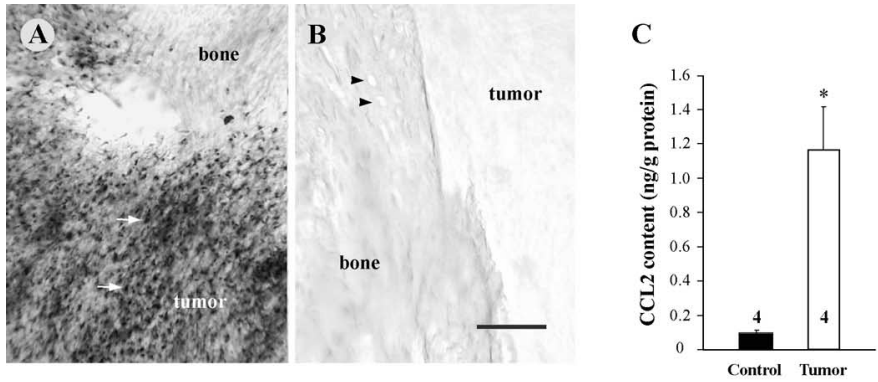

Figure 6. CCL2-ir occurred in tumors generated by fibrosarcoma cells. $\boldsymbol{A}$, Image demonstrating CCL2-ir in tumor cells (arrows) but not the bone. $B, C C L 2$-ir was absent when the primary antiserum was preincubated with $C C L 2$. Arrowheads indicate lacunae in the bone. Scale bar, $80 \mu \mathrm{m}$. Images in $\boldsymbol{A}$ and $\boldsymbol{B}$ were collected at the same magnification using bright-field microscopy. $\boldsymbol{C}$, CCL2 content in the tumor was confirmed by immunoassay in tissue homogenates of the tumor region in tumor-bearing mice. A comparable region of the contralateral hindlimb was used as the control. D, CCL2 was measured by immunoassay in microperfusates of the fibrosarcoma tumors. The control was a comparable region of the hindlimb in naive mice. *Significantly different from control at $p<0.05$ (Student's $t$ test). Values inside the bars represent the sample size.

7B). To determine whether CCL2 in the culture medium conditioned by fibrosarcoma cells was necessary to increase $\alpha 2 \delta 1$ subunit mRNA in DRG neurons, we determined whether the conditioned medium would alter the level of mRNA for the $\alpha 2 \delta 1$ subunit and whether immunoneutralization of CCL2 in the fibrosarcoma cell-conditioned medium would block the effect. Although treatment of DRG neurons from naive mice for $2 \mathrm{~h}$ with fibrosarcoma cell-conditioned medium did not change their functional properties acutely, the same treatment was sufficient to increase the level of mRNA for the $\mathrm{Ca}^{2+}$ channel subunit $\alpha 2 \delta 1$ by $50 \%$ (fibrosarcoma cell conditioned medium: $154 \pm 24 \%$ of control, $n=11$; control: $100 \pm 9 \%, n=12 ; p<0.05$, Student's $t$ test). However, results from immunoneutralization experiments indicated that CCL2 alone in the fibrosarcoma cell-conditioned medium was not necessary to increase the level of mRNA for the $\alpha 2 \delta 1$ subunit. Preincubation of the conditioned medium with $7.5 \mu \mathrm{g} / \mathrm{ml}$ goat anti-CCL2 for $1 \mathrm{~h}$ did not attenuate the effect of the conditioned medium on the level of mRNA for the $\alpha 2 \delta 1$ subunit (data not shown). The concentration of antibody was based on the manufacturer's technical information for maximum immunoneutralization of $40 \mathrm{ng} / \mathrm{ml}$ CCL2 2

DRG cultures are mixtures of neurons and supporting cells. To determine whether CCL2 had direct effects on the neurons in our cultures, we tested whether CCL2 evoked changes in $\left[\mathrm{Ca}^{2+}\right]_{\mathrm{i}}$ in small DRG neurons. DRG neurons from naive mice were used after $40-48 \mathrm{~h}$ in vitro in control medium. CCL2 was superfused at

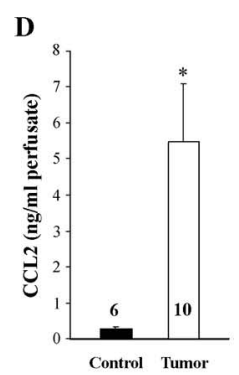

a concentration of $100 \mathrm{~nm}$ because this concentration was effective in evoking a $\mathrm{Ca}^{2+}$ transient in neonatal DRG neurons (Oh et al., 2001). Although no independent effect of CCL2 on $\left[\mathrm{Ca}^{2+}\right]_{i}$ was noted during a 5 min superfusion, this treatment increased the occurrence of a $\mathrm{Ca}^{2+}$ transient in small DRG neurons in response to $25 \mathrm{mM} \mathrm{KCl}$ (CCL2, 8 of 11; control, 3 of 13; $p<0.05$, Fisher's exact test). Therefore, CCL2 had a direct effect on neurons in the DRG cultures.

\section{Discussion}

Mechanical and thermal hyperalgesia occur in a variety of models of cancer pain. In the fibrosarcoma model of cancer pain, which used the same cell line as the present studies, C-fiber nociceptors located adjacent to tumors become sensitized as indicated by the occurrence of spontaneous activity and a decreased threshold to heat (Cain et al., 2001). Tumor-mediated changes in sensory transduction in vivo may be because of neuroactive chemicals released by cancer cells, inflammatory mediators released by immune cells in response to tumor-evoked damage of surrounding tissue, mechanical compression of nerves, and ischemia. We developed a novel DRG/fibrosarcoma coculture model to determine whether factors released from tumor cells could evoke changes in primary afferent neurons that contribute to cancer-associated hyperalgesia. Using this model in parallel with DRG neurons exposed to tumors in vivo, we have documented long-term phenotypic changes in primary afferent neurons that are associated with hyperalgesia in cancer pain. Specifically, we demonstrated increased basal $\left[\mathrm{Ca}^{2+}\right]_{\mathrm{i}}$ in small primary afferent neurons from tumor-bearing mice as well as increased function of voltage-dependent $\mathrm{Ca}^{2+}$ channels and TRPV1 receptors. These changes, which likely contribute to the pain-related behaviors observed in vivo, were reproduced in the DRG/fibrosarcoma coculture model. Furthermore, addition of CCL2 in vitro was sufficient to increase expression of mRNA for the $\mathrm{Ca}^{2+}$ channel subunit $\alpha 2 \delta 1$ in DRG neurons.

An increase in basal $\left[\mathrm{Ca}^{2+}\right]_{\mathrm{i}}$ in small DRG neurons was noted in neurons isolated from tumor-bearing mice and neurons cocultured with fibrosarcoma cells. A similar change was noted in some models of neuropathic pain (Kawamata and Omote, 1996; Kostyuk et al., 1999). An increase in $\left[\mathrm{Ca}^{2+}\right]_{\mathrm{i}}$ can have profound physiological consequences, including activation of $\mathrm{Ca}^{2+}$ / calmodulin-dependent protein kinase (Miller and Kennedy, 1986; Hanson and Schulman, 1992) and protein kinase C (Chen and Huang, 1992), which can increase gene expression at the level of the soma (Seybold et al., 2006) or increase transduction of sensory receptors at the level of the nerve terminal (Regehr et al., 1994). In DRG neurons, a large increase in $\left[\mathrm{Ca}^{2+}\right]_{\mathrm{i}}$ from the entry of extracellular $\mathrm{Ca}^{2+}$ through $\mathrm{Ca}^{2+}$ channels is balanced by extrusion of $\mathrm{Ca}^{2+}$ by plasma membrane ATP-dependent $\mathrm{Ca}^{2+}$ pumps and the $\mathrm{Na}^{+} / \mathrm{Ca}^{2+}$ exchanger (Thayer and Miller, 1990; Werth et al., 1996), as well as $\left[\mathrm{Ca}^{2+}\right]_{\mathrm{i}}$ buffering systems that 
A

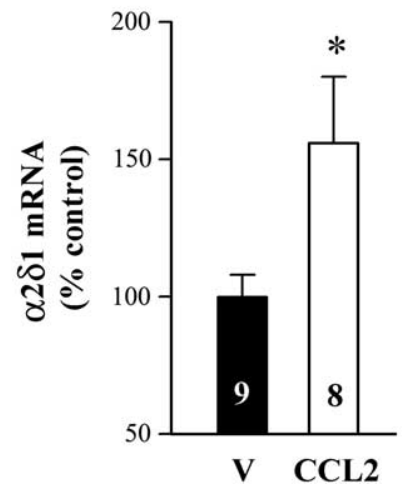

B

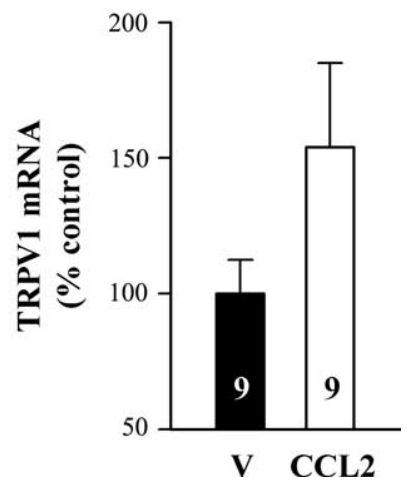

Figure 7. CCL2 increased the mRNA of target genes in DRG neurons from naive mice. Dissociated DRGs were maintained in vitro for $40 \mathrm{~h}$ before addition of CCL2 (final concentration, 10 $\mathrm{ng} / \mathrm{ml}$ ) or vehicle (V), and samples were processed for mRNA after $2 \mathrm{~h}$ of treatment. Quantitative reverse transcriptase-PCR was used to measure $m R N A$, and values for the target gene were normalized to the reference gene S15 within each sample. Data were then normalized to the average for the naive group within each procedure for isolation of mRNA and are expressed as percentage of control. *Significantly different from vehicle at $p<0.05$ (Student's $t$ test). Values inside the bars represent the sample size.

include cytoplasmic $\mathrm{Ca}^{2+}$-binding proteins, endoplasmic reticulum, and mitochondria (Werth and Thayer, 1994; Svichar et al., 1997; Verkhratsky and Petersen, 1998). Alterations in one or more of these processes most likely contributed to the observed increases in the amplitude and duration of the $\mathrm{Ca}^{2+}$ transient evoked by $50 \mathrm{~mm} \mathrm{KCl}$ in DRG neurons exposed to fibrosarcoma cells.

It is likely that the increased occurrence of a $\mathrm{Ca}^{2+}$ transient in response to $25 \mathrm{mM} \mathrm{KCl}$ in small DRG neurons from tumorbearing mice in vitro was functionally related to the mechanical hyperalgesia observed in vivo because the change was associated with an increased level of mRNA for the $\mathrm{Ca}^{2+}$ channel subunit $\alpha 2 \delta 1$. The $\alpha 2 \delta 1$ subunit increases the density of voltagedependent $\mathrm{Ca}^{2+}$ channels in the plasma membrane and shifts the current-voltage curve in a hyperpolarizing direction, thereby increasing the probability of channel opening (Klugbauer et al., 2003). Mostly noted for increasing the function of high-voltageactivated channels involved in neurotransmission (N- and P/Qtypes), the $\alpha 2 \delta$ subunits are also implicated in increasing the density of T-type channels in the membrane (Perez-Reyes, 2003; Dubel et al., 2004). T-type channels contribute to nociceptor excitability (Bourinet et al., 2005; Nelson et al., 2005), and inhibitors of T-type channels attenuate the hyperalgesia that accompanies neuropathic pain (Flatters and Bennett, 2004; Todorovic et al., 2004). The efficacy of gabapentin in the treatment of neuropathic pain is associated with the upregulation of the $\alpha 2 \delta 1$ subunit in DRG neurons and the binding of gabapentin to this subunit, thereby blocking channel function (Bourinet and Zamponi, 2005). Our evidence that gabapentin had no effect in control neurons but attenuated responses in DRG neurons affected by fibrosarcoma cells is consistent with changes in DRG neurons from transgenic mice overexpressing the $\alpha 2 \delta 1$ subunit (Li et al., 2006). Furthermore, the antihyperalgesic effect of gabapentin is consistent with a previous report in which gabapentin ameliorated movement-associated pain in a model of murine bone cancer (Peters et al., 2005) and lends additional support to the use of gabapentin in treatment of cancer pain.

The increased expression of TRPV1 mRNA in DRG neurons from tumor-bearing mice is consistent with a recent report in the

same model (Niiyama et al., 2007). The increase in mRNA was accompanied by a functional increase in the proportion of small DRG neurons that responded to capsaicin, and the change in tumor-bearing mice was paralleled by increased TRPV1 receptor immunoreactivity and function in DRG neurons cocultured with fibrosarcoma cells. These changes are consistent with the sensitization of C-fibers to heat stimuli in fibrosarcoma tumor-bearing mice (Cain et al., 2001). Moreover, thermal hyperalgesia occurs in a variety of cancer pain models (Menendez et al., 2003; Asai et al., 2005). Whereas increased expression of TRPV1 in DRG neurons has been correlated with thermal hyperalgesia in models of persistent pain (Numazaki and Tominaga, 2004), this channel may also contribute to mechanical hyperalgesia. Blockade of TRPV1 channels and downregulation of TRPV1 in DRG neurons attenuates mechanical hyperalgesia in a model of neuropathic pain (Christoph et al., 2007). Similarly, TRPV1 receptors have been implicated in movement-evoked nocifensive behaviors in a model of bone cancer pain (Ghilardi et al., 2005). The fact that ATP responses were not increased like TRPV1 and voltagesensitive $\mathrm{Ca}^{2+}$ channel function indicates that cancer cells had selective effects on specific nociceptive transduction channels in small DRG neurons.

The functional changes observed in DRG neurons were most likely because of changes in gene expression. Data from three different experimental approaches support this conclusion. First, when DRG neurons were incubated acutely with fibrosarcoma cell-conditioned medium, no change in response was observed to either $25 \mathrm{~mm} \mathrm{KCl}$ or capsaicin. Second, when L3-L6 DRGs ipsilateral to the tumor were isolated from tumor-bearing mice and maintained in vitro in the absence of fibrosarcoma cells for 20-28 $\mathrm{h}$, small neurons exhibited increased responsiveness to $25 \mathrm{~mm}$ $\mathrm{KCl}$ and capsaicin many hours after the neurons had been removed from the cancer cell environment. Third, the amounts of mRNA for the $\mathrm{Ca}^{2+}$ channel subunit $\alpha 2 \delta 1$ and TRPV1 receptor were elevated in DRGs ipsilateral to the tumor in tumor-bearing mice. Finally, the level of mRNA for the $\alpha 2 \delta 1$ subunit increased in DRG cultures from naive mice within $2 \mathrm{~h}$ of addition of cancer cell-conditioned medium. Therefore, the mechanisms underlying the functional changes most likely involve long-term changes in gene expression rather than short-term covalent modification of receptors and ion channels. The coculture model promises to have significant value in defining how products released from tumor cells generate pronociceptive or inhibitory proteins in DRG neurons. One of those mediators is CCL2.

To date, the relationship between CCL2 and DRG neurons in persistent pain has focused on the upregulation of CCL2 and its cognate receptor, CCR2, in models of neuronal injury (Tanaka et al., 2004; White et al., 2005). Our data are the first to support a role for CCL2 in regulating gene expression in DRG neurons. CCR receptors are G-protein-coupled receptors that stimulate phosphoinositide-3 kinase (PI3 kinase) and extracellular receptor kinase (ERK) in other cell types (Werle et al., 2002; Callewaere et al., 2007). Upregulation of TRPV1 in DRG neurons is partially dependent on ERK and PI3 kinase (Bron et al., 2003), but little is known about the intracellular pathways that contribute to expression of the $\mathrm{Ca}^{2+}$ channel subunit $\alpha 2 \delta 1$ in neurons. It remains to be determined whether CCL2-evoked changes in mRNA were mediated by CCR2, CCR4, or another chemokine receptor. DRG neurons from naive adult animals express few transcripts for CCR2 mRNA (White et al., 2005). Although isolation and dissociation of DRG neurons constitutes nerve injury, $>3 \mathrm{~d}$ are required for upregulation of CCR2 expression and functional receptors in a model of chronic compression of the DRG 
(White et al., 2005; Sun et al., 2006). Therefore, it is unlikely that CCR2 receptors mediated the effect of CCL2 on mRNA levels. CCR4 receptors are a possibility given that mRNA for CCR4 receptors has been isolated from cultured neonatal DRG neurons (Oh et al., 2001) and CCL 2 can activate CCR 4 receptors (Power et al., 1995). Finally, although it is possible that changes in expression of neuron-specific genes was mediated by an effect of CCL2 on supporting cells in the DRG cultures, evidence that CCL2 acutely enhanced the occurrence of $\mathrm{Ca}^{2+}$ transients in response to $25 \mathrm{~mm} \mathrm{KCl}$ supports a direct action of CCL2 on DRG neurons in these experiments.

\section{Conclusion}

We demonstrated that maintenance of adult DRG neurons in medium conditioned by tumor cells produced changes in biochemical markers and cellular activity that are consistent with the tumor-evoked hyperalgesia observed in vivo. Importantly, the increased functional responses that occurred when DRG neurons and fibrosarcoma cells were cocultured in vitro parallel changes that were observed in DRG neurons isolated from tumor-bearing mice, thereby providing evidence of direct effects of fibrosarcoma cells on DRG cells. Biochemical studies using the coculture model implicate CCL2 as a mediator in evoking phenotypic changes in DRG neurons.

\section{References}

Abbadie C (2005) Chemokines, chemokine receptors and pain. Trends Immunol 26:529-534.

Abbadie C, Lindia JA, Cumiskey AM, Peterson LB, Mudgett JS, Bayne EK, DeMartino JA, MacIntyre DE, Forrest MJ (2003) Impaired neuropathic pain responses in mice lacking the chemokine receptor CCR2. Proc Natl Acad Sci USA 100:7947-7952.

Asai H, Ozaki N, Shinoda M, Nagamine K, Tohnai I, Ueda M, Sugiura Y (2005) Heat and mechanical hyperalgesia in mice model of cancer pain. Pain 117:19-29.

Bourinet E, Zamponi GW (2005) Voltage gated calcium channels as targets for analgesics. Curr Top Med Chem 5:539-546.

Bourinet E, Alloui A, Monteil A, Barrere C, Couette B, Poirot O, Pages A, McRory J, Snutch TP, Eschalier A, Nargeot J (2005) Silencing of the Cav3.2 T-type calcium channel gene in sensory neurons demonstrates its major role in nociception. EMBO J 24:315-324.

Brant JM (1998) Cancer-related neuropathic pain. Nurse Pract Forum 9:154-162.

Bron R, Klesse LJ, Shah K, Parada LF, Winter J (2003) Activation of Ras is necessary and sufficient for upregulation of vanilloid receptor type 1 in sensory neurons by neurotrophic factors. Mol Cell Neurosci 22:118-132.

Cain DM, Wacnik PW, Turner M, Wendelschafer-Crabb G, Kennedy WR, Wilcox GL, Simone DA (2001) Functional interactions between tumor and peripheral nerve: changes in excitability and morphology of primary afferent fibers in a murine model of cancer pain. J Neurosci 21:9367-9376.

Callewaere C, Banisadr G, Rostène W, Parsadaniantz SM (2007) Chemokines and chemokine receptors in the brain: implication in neuroendocrine regulation. J Mol Endocrinol 38:355-363.

Caterina MJ, Julius D (2001) The vanilloid receptor: a molecular gateway to the pain pathway. Annu Rev Neurosci 24:487-517.

Chen L, Huang LY (1992) Protein kinase C reduces $\mathrm{Mg}^{2+}$ block of NMDAreceptor channels as a mechanism of modulation. Nature 356:521-523.

Christoph T, Gillen C, Mika J, Grunweller A, Schafer MK, Schiene K, Frank R, Jostock R, Bahrenberg G, Weihe E, Erdmann VA, Kurreck J (2007) Antinociceptive effect of antisense oligonucleotides against the vanilloid receptor VR1/TRPV1. Neurochem Int 50:281-290.

Clohisy DR, Ogilvie CM, Carpenter RJ, Ramnaraine ML (1996) Localized, tumor-associated osteolysis involves the recruitment and activation of osteoclasts. J Orthop Res 14:2-6.

Dirajlal S, Pauers LE, Stucky CL (2003) Differential response properties of IB(4)-positive and -negative unmyelinated sensory neurons to protons and capsaicin. J Neurophysiol 89:513-524.

Dubel SJ, Altier C, Chaumont S, Lory P, Bourinet E, Nargeot J (2004)
Plasma membrane expression of T-type calcium channel alpha(1) subunits is modulated by high voltage-activated auxiliary subunits. J Biol Chem 279:29263-29269.

Flatters SJ, Bennett GJ (2004) Ethosuximide reverses paclitaxel- and vincristine-induced painful peripheral neuropathy. Pain 109:150-161.

Ghilardi JR, Rohrich H, Lindsay TH, Sevcik MA, Schwei MJ, Kubota K, Halvorson KG, Poblete J, Chaplan SR, Dubin AE, Carruthers NI, Swanson D, Kuskowski M, Flores CM, Julius D, Mantyh PW (2005) Selective blockade of the capsaicin receptor TRPV1 attenuates bone cancer pain. J Neurosci 25:3126-3131.

Gurnett CA, De Waard M, Campbell KP (1996) Dual function of the voltage-dependent $\mathrm{Ca}^{2+}$ channel alpha 2 delta subunit in current stimulation and subunit interaction. Neuron 16:431-440.

Hanson PI, Schulman H (1992) Inhibitory autophosphorylation of multifunctional $\mathrm{Ca} 2+/$ calmodulin-dependent protein kinase analyzed by sitedirected mutagenesis. J Biol Chem 267:17216-172124.

He ML, Zemkova H, Koshimizu TA, Tomic M, Stojilkovic SS (2003) Intracellular calcium measurements as a method in studies on activity of purinergic P2X receptor channels. Am J Physiol Cell Physiol 285:C467-C479.

Hiura A, Sakamoto Y (1987) Quantitative estimation of the effects of capsaicin on the mouse primary sensory neurons. Neurosci Lett 76:101-106.

Honore P, Rogers SD, Schwei MJ, Salak-Johnson JL, Luger NM, Sabino MC, Clohisy DR, Mantyh PW (2000) Murine models of inflammatory, neuropathic and cancer pain each generates a unique set of neurochemical changes in the spinal cord and sensory neurons. Neuroscience 98:585-598.

Kawamata M, Omote K (1996) Involvement of increased excitatory amino acids and intracellular $\mathrm{Ca}^{2+}$ concentration in the spinal dorsal horn in an animal model of neuropathic pain. Pain 68:85-96.

Kerschensteiner M, Schwab ME, Lichtman JW, Misgeld T (2005) In vivo imaging of axonal degeneration and regeneration in the injured spinal cord. Nat Med 11:572-577.

Khasabova IA, Simone DA, Seybold VS (2002) Cannabinoids attenuate depolarization-dependent $\mathrm{Ca}^{2+}$ influx in intermediate-size primary afferent neurons of adult rats. Neuroscience 115:613-625.

Klugbauer N, Marais E, Hofmann F (2003) Calcium channel alpha2delta subunits: differential expression, function, and drug binding. J Bioenerg Biomembr 35:639-647.

Kostyuk E, Svichar N, Shishkin V, Kostyuk P (1999) Role of mitochondrial dysfunction in calcium signalling alterations in dorsal root ganglion neurons of mice with experimentally-induced diabetes. Neuroscience 90:535-541.

Li CY, Zhang XL, Matthews EA, Li KW, Kurwa A, Boroujerdi A, Gross J, Gold MS, Dickenson AH, Feng G, Luo ZD (2006) Calcium channel alpha2delta1 subunit mediates spinal hyperexcitability in pain modulation. Pain 125:20-34.

Luo ZD, Chaplan SR, Higuera ES, Sorkin LS, Stauderman KA, Williams ME, Yaksh TL (2001) Upregulation of dorsal root ganglion $\alpha_{2} \delta$ calcium channel subunit and its correlation with allodynia in spinal nerve-injured rats. J Neurosci 21:1868-1875.

Menendez L, Lastra A, Fresno MF, Llames S, Meana A, Hidalgo A, Baamonde A (2003) Initial thermal heat hypoalgesia and delayed hyperalgesia in a murine model of bone cancer pain. Brain Res 969:102-109.

Mercadante S (1997) Malignant bone pain: pathophysiology and treatment. Pain 69:1-18.

Miller SG, Kennedy MB (1986) Regulation of brain type II Ca2+/ calmodulin-dependent protein kinase by autophosphorylation: a Ca2+triggered molecular switch. Cell 44:861-870.

Nelson MT, Joksovic PM, Perez-Reyes E, Todorovic SM (2005) The endogenous redox agent $\mathrm{L}$-cysteine induces $\mathrm{T}$-type $\mathrm{Ca}^{2+}$ channel-dependent sensitization of a novel subpopulation of rat peripheral nociceptors. J Neurosci 25:8766-8775.

Newton RA, Bingham S, Case PC, Sanger GJ, Lawson SN (2001) Dorsal root ganglion neurons show increased expression of the calcium channel alpha2delta-1 subunit following partial sciatic nerve injury. Brain Res Mol Brain Res 95:1-8.

Niiyama Y, Kawamata T, Yamamoto J, Omote K, Namiki A (2007) Bone cancer increases transient receptor potential vanilloid subfamily 1 expression within distinct subpopulations of dorsal root ganglion neurons. Neuroscience, in press. 
Numazaki M, Tominaga M (2004) Nociception and TRP channels. Curr Drug Targets CNS Neurol Disord 3:479-485.

Oh SB, Tran PB, Gillard SE, Hurley RW, Hammond DL, Miller RJ (2001) Chemokines and glycoprotein 120 produce pain hypersensitivity by directly exciting primary nociceptive neurons. J Neurosci 21:5027-5035.

Pearce RJ, Duchen MR (1994) Differential expression of membrane currents in dissociated mouse primary sensory neurons. Neuroscience 63:1041-1056.

Perez-Reyes E (2003) Molecular physiology of low-voltage-activated t-type calcium channels. Physiol Rev 83:117-161.

Peters CM, Ghilardi JR, Keyser CP, Kubota K, Lindsay TH, Luger NM, Mach DB, Schwei MJ, Sevcik MA, Mantyh PW (2005) Tumor-induced injury of primary afferent sensory nerve fibers in bone cancer pain. Exp Neurol 193:85-100.

Pfaffl MW (2001) A new mathematical model for relative quantification in real-time RT-PCR. Nucleic Acids Res 29:e45.

Power CA, Meyer A, Nemeth K, Bacon KB, Hoogewerf AJ, Proudfoot AE, Wells TN 1995 Molecular cloning and functional expression of a novel CC chemokine receptor cDNA from a human basophilic cell line. J Biol Chem 270:19495-19500.

Regehr WG, Delaney KR, Tank DW (1994) The role of presynaptic calcium in short-term enhancement at the hippocampal mossy fiber synapse. J Neurosci 14:523-537.

Ruscheweyh R, Sandkuhler J (2005) Long-range oscillatory $\mathrm{Ca}^{2+}$ waves in rat spinal dorsal horn. Eur J Neurosci 22:1967-1976.

Scott BS (1977) Adult mouse dorsal root ganglia neurons in cell culture. J Neurobiol 8:417-427.

Seybold VS, Coicou LG, Groth RD, Mermelstein PG (2006) Substance P initiates NFAT-dependent gene expression in spinal neurons. J Neurochem 97:397-407.

Shimoyama M, Tanaka K, Hasue F, Shimoyama N (2002) A mouse model of neuropathic cancer pain. Pain 99:167-174.

Sun JH, Yang B, Donnelly DF, Ma C, LaMotte RH (2006) MCP-1 enhances excitability of nociceptive neurons in chronically compressed dorsal root ganglia. J Neurophysiol 96:2189-2199.

Svichar N, Kostyuk P, Verkhratsky A (1997) Mitochondria buffer $\mathrm{Ca}^{2+}$ entry but not intracellular $\mathrm{Ca}^{2+}$ release in mouse DRG neurones. NeuroReport 8:3929-3932.

Tanaka T, Minami M, Nakagawa T, Satoh M (2004) Enhanced production of monocyte chemoattractant protein-1 in the dorsal root ganglia in a rat model of neuropathic pain: possible involvement in the development of neuropathic pain. Neurosci Res 48:463-469.

Thayer SA, Miller RJ (1990) Regulation of the intracellular free calcium concentration in single rat dorsal root ganglion neurones in vitro. J Physiol (Lond) 425:85-115.

Thut PD, Wrigley D, Gold MS (2003) Cold transduction in rat trigeminal ganglia neurons in vitro. Neuroscience 110:1071-1083.

Todorovic SM, Pathirathna S, Brimelow BC, Jagodic MM, Ko SH, Jiang X, Nilsson KR, Zorumski CF, Covey DF, Jevtovic-Todorovic V (2004) 5beta-reduced neuroactive steroids are novel voltage-dependent blockers of T-type $\mathrm{Ca}^{2+}$ channels in rat sensory neurons in vitro and potent peripheral analgesics in vivo. Mol Pharmacol 66:1223-1235.

Ueda A, Okuda K, Ohno S, Shirai A, Igarashi T, Matsunaga K, Fukushima J, Kawamoto S, Ishigatsubo Y, Okubo T (1994) NF-kappa B and Sp1 regulate transcription of the human monocyte chemoattractant protein-1 gene. J Immunol 153:2052-2063.

Urban L, Dray A (1993) Actions of capsaicin on mouse dorsal root ganglion cells in vitro. Neurosci Lett 157:187-190.

Urch CE, Donovan-Rodriguez T, Dickenson AH (2003) Alterations in dorsal horn neurones in a rat model of cancer-induced bone pain. Pain 106:347-356.

Verkhratsky AJ, Petersen OH (1998) Neuronal calcium stores. Cell Calcium 24:333-343.

Wacnik PW, Eikmeier LJ, Ruggles TR, Ramnaraine ML, Walcheck BK, Beitz AJ, Wilcox GL (2001) Functional interactions between tumor and peripheral nerve: morphology, algogen identification, and behavioral characterization of a new murine model of cancer pain. J Neurosci 21:9355-9366.

Wacnik PW, Kehl LJ, Trempe TM, Ramnaraine ML, Beitz AJ, Wilcox GL (2003) Tumor implantation in mouse humerus evokes movementrelated hyperalgesia exceeding that evoked by intramuscular carrageenan. Pain 101:175-186.

Walker D, De Waard M (1998) Subunit interaction sites in voltagedependent $\mathrm{Ca} 2+$ channels: role in channel function. Trends Neurosci 214:148-154.

Wang M, Offord J, Oxender DL, Su TZ (1999) Structural requirement of the calcium-channel subunit alpha2delta for gabapentin binding. Biochem J 342:313-320.

Werle M, Schmal U, Hanna K, Kreuzer J (2002) MCP-1 induces activation of MAP-kinases ERK, JNK and p38 MAPK in human endothelial cells. Cardiovasc Res 56:284-292.

Werth JL, Thayer SA (1994) Mitochondria buffer physiological calcium loads in cultured rat dorsal root ganglion neurons. J Neurosci 14:348-356.

Werth JL, Usachev YM, Thayer SA (1996) Modulation of calcium efflux from cultured rat dorsal root ganglion neurons. J Neurosci 16:1008-1015.

White FA, Sun J, Waters SM, Ma C, Ren D, Ripsch M, Steflik J, Cortright DN, Lamotte RH, Miller RJ (2005) Excitatory monocyte chemoattractant protein-1 signaling is up-regulated in sensory neurons after chronic compression of the dorsal root ganglion. Proc Natl Acad Sci USA 102:14092-14097.

Zachariae CO, Anderson AO, Thompson HL, Appella E, Mantovani A, Oppenheim JJ, Matsushima K (1990) Properties of monocyte chemotactic and activating factor (MCAF) purified from a human fibrosarcoma cell line. J Exp Med 171:2177-2182.

Zhong J, Dietzel ID, Wahle P, Kopf M, Heumann R (1999) Sensory impairments and delayed regeneration of sensory axons in interleukin-6deficient mice. J Neurosci 19:4305-4313. 